\title{
Water-rock interaction on the development of granite gneissic weathered profiles in Garhwal Lesser Himalaya, India
}

\author{
S VyShNAVI and R ISLAM* \\ Wadia Institute of Himalayan Geology, Dehradun 248 001, India. \\ *Corresponding author. e-mail: rislam@wihg.res.in
}

The development and sustainability of weathered profiles are very difficult in the Himalaya due to its complex lithology, tectonic history and fast erosion. Despite this, two weathered profiles namely $\mathrm{WPa}$ (weathered profile a) and WPb (weathered profile b) which have sustained erosion are developed on porphyry granite gneiss and granite gneissic lithology in Alaknanda valley of the Garhwal Lesser Himalaya. Systematic sampling of these two weathered profiles was done from bottom to top and they were chemically analysed to understand the elemental mobility in each profile. Major, trace and rare earth element studies show dissimilar behaviour with the advancement of weathering. In WPa profile, the CIA value of LAR (LAR) is 50 which reveals that the rock has not suffered any alteration but in $\mathrm{WPb}$ profile, the CIA value of LAR is 64 which indicates significant amount of chemical alteration. A-CN-K projection also exhibits similar behaviour. Further, the relative mobility of all the major and trace elements show variable elemental distribution in both the profiles. Enrichment of $\mathrm{Mg}, \mathrm{Fe}, \mathrm{Ti}, \mathrm{Al}$, $\mathrm{Co}, \mathrm{Ni}, \mathrm{Zr}, \mathrm{LREE}$ and depletion of Na, K, P, Ca, Si, LILE and HFSE are observed in WPa profile; while the depletion of $\mathrm{Na}, \mathrm{K}, \mathrm{Ca}, \mathrm{P}, \mathrm{Si}$, HREE and enhancement of Fe, Mn, Ti, Sc, Co, Zr, LREE are noticed in WPb profile. The rare earth elements also show a dissimilar mobilization pattern in both the profiles due to their strong dependency on lithology, and corresponding climate and tectonic interaction. Contrasting elemental mobility in both the profiles depict the major role in disparity of lithological characters and subsequent development of fractures produced by the major thrust system (Ramgarh thrust) which made an easy passage for rain water, thus causing the development of a chemically altered profile in the Lesser Himalayan region. Further, the present study infers the climate and tectonic milieu which is responsible for the development of such weathered profiles in Himalayan sector.

\section{Introduction}

Weathering is an initial and complex process which is activated on the surface of the earth as soon as the rock/minerals are exposed to the earth's surface climatic conditions. This is a phenomenon of disintegration and decomposition of rock masses into small pieces through various physical, chemical and biological actions that play a major role in altering/framing the landscape. Since many years, pioneering work has been done on these weathering aspects by Goldich (1938); Anderson and Hawkes (1958); Grant (1963); Garrels and Mackenzie (1971); Nesbitt (1979); Nesbitt and Young (1982, 1984, 1989); Middelburg et al. (1988); McLennan (1993); Condie et al. (1995); Fedo et al. (1995); Sharma and Rajamani (2000); Turner et al. (2003); Little and Lee (2006); Dosseto et al. (2008); Li et al. (2008); Rajamani et al. (2009); Vyshnavi et al. (2013) and others. Weathering process operates

Keywords. Chemical alteration; granite gneisses; elemental mobility; climate-tectonic interaction; Lesser Himalaya. 
in an open system and has been studied from long time due to various processes that are involved in the transformation of rock into soil that has provided space to the development of different secondary minerals through variable elemental mobility. These weathering processes especially chemical weathering are responsible for the several factors such as lowering of greenhouse gas $\left(\mathrm{CO}_{2}\right)$, keeping the earth in equilibrium, liberation of major-minor ions in transformation of rock into soil and retainment of residual concentration of some economic minerals. The chemical weathering is restricted to the interaction of rock and water, generally rain water containing organic and inorganic acids derived from decay of litter in the soil zone (Nesbitt and Young 1989). Therefore, understanding the processes of weathering is important as it directly or indirectly relates to our day-to-day life and is widely connected to the earth's surface conditions through addition and deletion of mineral atoms, breakdown of ligands and the formation of new minerals in different combinations. This paper presents a case study on chemical weathering in association with physical disintegration to understand the significance of lithology in addition to the role of climate and tectonics in Himalayan region.

The Himalayan mountain range occurred due to the collision between Indian and Eurasian plates. The region is subjected to continuous stress build up with neo/active tectonics, which resulted in the development of numerous thrust and fault systems. The altitudinal variation is very wide in the Himalaya and it holds one of the higher processes in weathering intensity in the world (Chauhan et al. 2004). The Himalayan terrain is also known for its fast erosion. Both the physical and chemical weathering processes are responsible for the generation of sediments in the large drainage system, viz., river Ganga. The Lesser Himalayan region receives heavy rainfall, hence the rocks are subjected to chemical weathering and therefore it gives more insights for weathering studies in the region. In totality, the extent of weathering is controlled by the climate and tectonic conditions in the region and defines the nature of the sediments in the final deposition.

As already stated, the rate of erosion is very high in the Himalaya, therefore it is very difficult for the preservation of chemically weathered in situ profiles. And these weathered profiles will be preserved only when the weathering processes exceed erosion. In this study, we have identified and discussed two such weathered profiles which have sustained erosional processes, viz., WPa (weathered profile a) and $\mathrm{WPb}$ (weathered profile b). These weathered profiles have developed respectively on porphyry granite gneissic and granite gneissic rocks of
Garhwal Lesser Himalaya (Debguru porphyroids, Valdiya 1980). Both the profiles are developed in nominal aerial distance and hence experience almost similar tectonic and climatic conditions (subtropical humid climate). Here, we have attempted to understand the elemental mobility that is taking part in in situ weathered profiles during the chemical weathering processes, so that the microclimatic condition in the region is comprehended. This study will also help us in understanding the intensity of weathering, which is actually driven mainly by lithology, climate, tectonics and other factors like slope, vegetation, fractures, etc.

\section{Geology of the area}

Himalaya is broadly divided into five lithotectonic zones from south to north and each zone having its distinct physiographic features and geological history, viz., Outer or SubHimalaya, overlain by Lesser Himalaya, which further lays Higher Himalaya, Tethys Himalaya and Trans Himalaya (figure 1a and b). The SubHimalaya is separated from Lesser Himalaya by Main Boundary Thrust (MBT), further Lesser Himalaya is separated from Higher Himalaya by Main Central Thrust (MCT). The South Tibetan Detachment System (STDS) demarcates the boundary between Higher and Tethys Himalaya (Srivastava and Mitra 1994), whereas Trans Himalaya and Ladakh magmatic arc are marked by Indus Tsangpo Suture Zone (ITSZ). To the south of SubHimalaya, there exists Indo-Gangetic alluvium which is separated by Himalayan Frontal Thrust (HFT).

The study area is located in the Garhwal Lesser Himalayan region (figure 1c) and this sequence is restricted to a zone between Main Boundary Thrust (MBT) in south and Main Central Thrust (MCT) in the north. This is further divided into Inner Lesser Himalaya and Outer Lesser Himalaya separated by North Almora Thrust (NAT). These two units show difference in depositional history. However, many workers have also divided Lesser Himalaya into older and younger (Valdiya 1980; Srivastava and Mitra 1994; Ahmad et al. 2000; DeCelles et al. 2001; Richards et al. 2005; Célérier et al. 2009; Islam et al. 2011).

In Lesser Himalaya, Damtha (Precambrian) Formation is the oldest and forms the base of the Lesser Himalaya. To the north of Damtha Formation there exists Jaunsar Group, Mussorrie Group, Sirmur Group, Ramgarh Group and Almora Group. In between MBT and MCT ( $\simeq$ Vaikrita Thrust) there lie number of thrusts such as Ramgarh Thrust, North Almora Thrust, Tons Thrust, Munsiari Thrust and often some of those are folded. Structurally there lie two major thrust sheets in 

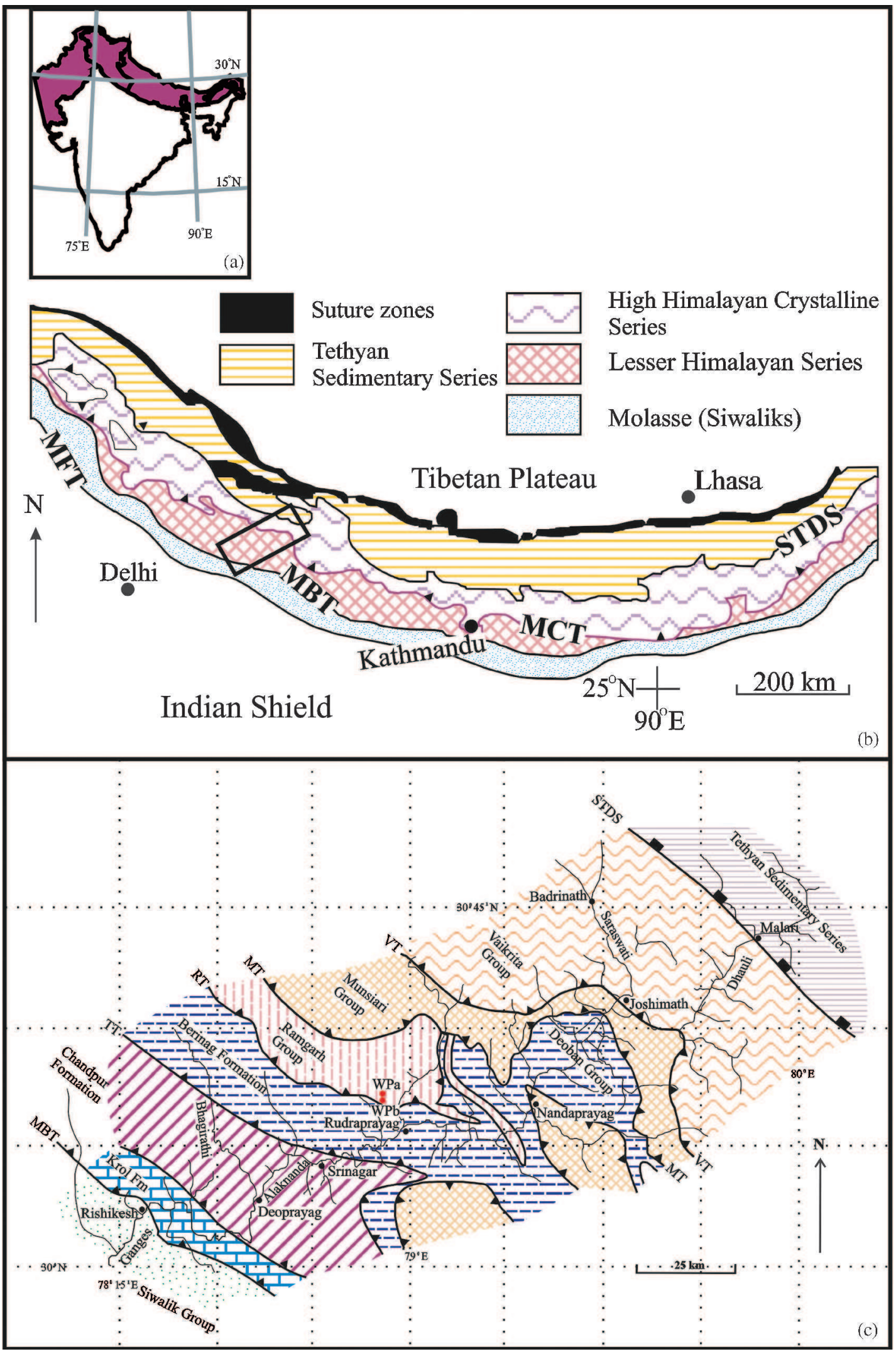

Figure 1. (a) Map of India showing the Himalayan segments. (b) Geological and structural map of the Himalaya showing the major lithotectonic divisions. Abbreviations. MFT: Main Frontal Thrust, MBT: Main Boundary Thrust, MCT: Main Central Thrust (after Ahmad et al. 2000). (c) Geological map of the Alaknanda section of Garhwal Lesser Himalaya showing the various lithotectonic units of Himalaya (after Ahmad et al. 2000). Rectangle in the map (b) shows the location of (c). STDS: South Tibetan detachment system, VT: Vaikrita Thrust, MT: Munsiari Thrust, RT: Ramgarh Thrust, TT: Tons Thrust, MBT: Main Boundary Thrust. Location of the WPa and WPb profiles are marked in red dots of Ramgarh group. 
Lesser Himalaya, viz., Ramgarh thrust sheet and Munsiari thrust sheet. The Ramgarh thrust sheet is defined at its lower boundary by Ramgarh Thrust and upper boundary by Munsiari/Almora Thrust.

The granitic gneisses of Ramgarh (also referred as Debguru Porphyroids) and Munsiari (Almora) groups of Lesser Himalaya are Proterozoic in age. Debguru Porphyroids or Ramgarh group of rocks (Heim and Gansser 1939; Valdiya 1980) is located at the base of Ramgarh thrust sheet. Compositionally and texturally Debguru Porphyroids $(\approx$ Ramgarh) are different from augen gneisses of the Almora Klippe (Valdiya 1980). Gneisses are biotite rich granitic gneisses and are characterized by alternate bands of quartz, feldspar and mica. At places, the rocks are mylonitized and show retrograde metamorphism. These granite gneisses are coarse-grained, well-foliated and exhibit distinct mineralogy. The strong preferred orientation of mica defines the foliation plane. The rock has a mineral assemblage of quartz, alkali feldspar, plagioclase, biotite and muscovite with minor amount of apatite, zircon, calcite, epidote and Fe-oxide. Geochemically these gneisses are enriched in silica and $\mathrm{K}_{2} \mathrm{O}$ with $\mathrm{A} / \mathrm{CNK}$ (molecular proportion of $\mathrm{Al}_{2} \mathrm{O}_{3} / \mathrm{CaO}+\mathrm{Na}_{2} \mathrm{O}+\mathrm{K}_{2} \mathrm{O}$ ) value $>1.1$, shows the presence of normative corundum (Islam et al. 2005) and have initial ratio of ${ }^{87} \mathrm{Sr} /{ }^{86} \mathrm{Sr}$ of $0.711-0.721$, which are generally high and initial $\varepsilon \mathrm{Nd}$ values range between -5.8 and -8.8 (Miller et al. 2000). These rocks are enriched in LREE and moderately depleted in HREE with a distinct negative $\mathrm{Eu}$ anomaly. On a multi-element spider diagram $\mathrm{Nb}$, Sr, P, and Ti exhibit negative anomalies and positive $\mathrm{Rb}$, Th and $\mathrm{U}$ anomalies (Islam et al. 2005). These are the typical characteristic features that belong to peraluminous S-type granite.

\section{Methodology}

\subsection{Sampling}

The identification of weathered profile is a very complex task. The in situ weathered profile should be identified in which signatures of fining upward and gradual change in colour can be observed during weathering advancement, i.e., least altered rock (LAR) to regolith. Adequate care should be taken during sampling to avoid mixing of the samples by any transported materials from the higher ridges or slumped materials from the topographic high.

Systematic field work was carried out and two weathered profiles were identified, namely $\mathrm{WPa}$ and $\mathrm{WPb}$. Both are located near Tilwara along the Tilwara-Mayali road section (figure $2 \mathrm{a}$ and $\mathrm{b}$ ) in the Garhwal Lesser Himalaya. The samples were collected from $\mathrm{WPa}$ profile which is located at
N30 $21^{\prime} 32.2^{\prime \prime}$; E78 $56^{\prime} 31.6^{\prime \prime}$; altitude $914 \pm 11 \mathrm{~m}$. The other weathered profile (WPb) is located at $\mathrm{N} 30^{\circ} 21^{\prime} 28.3^{\prime \prime}$; E78 $57^{\prime} 32^{\prime \prime}$; altitude of $861.6 \pm$ $10.5 \mathrm{~m}$. Both the profiles are exposed along Lastargad, a tributary of river Mandakini which in turn is a tributary of river Alaknanda; wherein river Alaknanda is one of the major tributaries of the river Ganga in the Garhwal Lesser Himalaya. The annual rainfall in the area varies between $\sim 1500$ and $2000 \mathrm{~mm}$.

The area or the topography is exclusively enclosed by rocks which are unweathered and weathered to different degrees. Systematic sampling is done from LAR at its base to regolith at the top of the profile. Sampling was done after vertical surface of the profile was scraped inward up to $\sim 0.1 \mathrm{~m}$ to minimize the effects of surface contamination and anthropogenic activities. The collected samples were packed in a cotton bag, then covered by ziplock bags to minimize mixing and contamination of the samples. The profile is identified with five zones, viz., LAR (exposed rock on the surface), saprock, saprolith, saprolite and regolith depending on the observed physical variations in mineralogy, grain size, colour, biologic activity, compactness, etc. (sketch of the weathered profiles are given in figure $2 \mathrm{a}$ and $\mathrm{b}$ ). Representative samples weighing about $1.5-2 \mathrm{~kg}$ were collected from each zone of individual weathered profile of $\mathrm{WPa}$ and $\mathrm{WPb}$ sections for the laboratory analysis, i.e., five representative samples were collected from both the weathered profiles. The vertical thickness of the identified weathered profile is measured $9 \mathrm{~m}$ for $\mathrm{WPa}$ and $8.4 \mathrm{~m}$ for $\mathrm{WPb}$.

\subsection{Analytical procedure}

The collected samples were air dried in the laboratory prior to analytical work and about $15 \mathrm{~g}$ of each sample was powdered to a mesh size of $-200 \mu \mathrm{m}$ in tema mill for geochemical analysis. Whole rock analysis was done by X-ray flourescence using Wave Length Dispersive XRF system (Siemens SRS 3000) for the analysis of major oxides and trace elements. About $5 \mathrm{~g}$ of each powdered sample was taken to make pressed pellets using polyvinyl alcohol as binding agent (Stork et al. 1987; Saini et al. 2000). The calibration of $\mathrm{XRF}$ system was done by a method of matrix correction based on intensities (Lucas-Tooth and Pyne 1964). The precision and accuracy of the analytical methods including instrumental performance were checked using several international reference standards of soil and sediments, e.g., SO-1, GSS-1, GSS-4, GXR-2, GXR-6, SCO-1, SGR-1, SDO-1, MAG-1, GSD-9, GSD-10, GSR-6 and BCS-267. The accuracy of measurement is better than $2 \%$ 


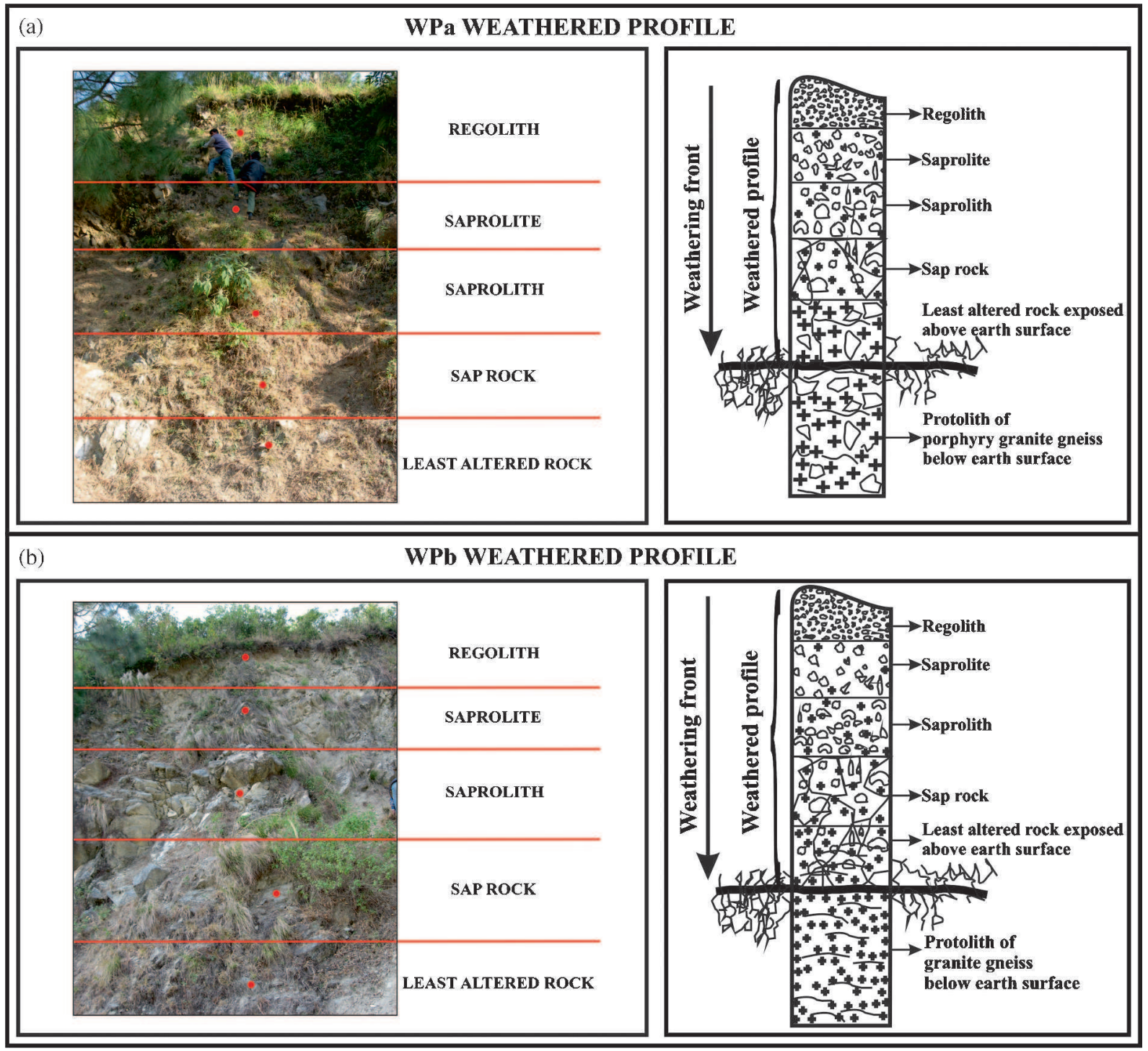

Figure 2. (a) Field photograph and sketch of WPa porphyry granite gneissic weathered profile in Alaknanda valley showing different altered layers. Red dots indicate the sample locations. (b) Field photograph and sketch of WPb granite gneissic weathered profile in Alaknanda valley showing different altered layers. Red dots indicate the sample locations.

for all major oxides except $\mathrm{P}_{2} \mathrm{O}_{5}, \mathrm{MnO}$; and trace elements are better than $5 \%$ and precision is $<2 \%$ (Purohit et al. 2010). About $5 \mathrm{~g}$ of each sample is taken to determine the loss of ignition (LOI) for total percentile studies. The samples were ignited at $1000^{\circ} \mathrm{C}$ for $4-8$ hours and were measured before and after ignition.

A wet ICP-MS technique (PerkinElmer) is used for REE analysis. About $0.1 \mathrm{~g}$ of each sample is taken in a Teflon crucible, $10 \mathrm{ml}$ of $2: 1$ acid mixture of concentrated $\mathrm{HF}: \mathrm{HNO}_{3}$ is added and heated at $180^{\circ} \mathrm{C}$ up to dryness. The procedure is repeated till the final dissolution of silica. $5 \mathrm{ml}$ of $\mathrm{HClO}_{4}$ is added and dried up to incipient dryness to remove all the excess fluoride present in the solution. Finally $10 \mathrm{ml} \mathrm{HNO}_{3}(10 \%)$ is added and heated for 10 minutes until clear solution is obtained and made up to $100 \mathrm{ml}$ with distilled water in a beaker. These solutions are stored in plastic bottles and are ready for the analysis. All the analyses were carried out at Wadia Institute of Himalayan Geology, Dehradun. Precision for REE is better than $10 \%$ (Khanna et al. 2009).

\section{Results}

The profiles were identified with the LAR at its base and successive layers are altered saprock, fractured saprolith, friable saprolite and regolith (includes top soil with humus). The rocks are highly fractured and altered in nature and falls in Grade IV of weathered rock of Ehlen (2005). The data of major oxides, trace elements and REE are presented in table 1 ( $a$ and $b$ ). 
Table 1. Geochemical data of WPa and WPb weathered profiles, Alaknanda valley (major oxides are in wt\%, trace, rare earth elements are in ppm and total iron as $\mathrm{Fe}_{2} \mathrm{O}_{3}$ ). Samples are arranged from LAR to regolith.

\begin{tabular}{|c|c|c|c|c|c|c|c|c|c|c|}
\hline Sample no. & WPa-5 & WPa-4 & WPa-3 & WPa-2 & WPa-1 & $\mathrm{WPb}-5$ & $\mathrm{WPb}-4$ & $\mathrm{WPb}-3$ & $\mathrm{WPb}-2$ & WPb-1 \\
\hline $\mathrm{SiO}_{2}$ & 73.8 & 73.55 & 65.58 & 67.86 & 64.42 & 75.62 & 76.9 & 75.05 & 78.95 & 69.5 \\
\hline $\mathrm{TiO}_{2}$ & 0.3 & 0.44 & 0.38 & 0.4 & 0.61 & 0.24 & 0.29 & 0.29 & 0.25 & 0.47 \\
\hline $\mathrm{Al}_{2} \mathrm{O}_{3}$ & 12.21 & 12.19 & 16.55 & 15.01 & 15.02 & 13.53 & 13.12 & 13.2 & 12.47 & 13.44 \\
\hline $\mathrm{Fe}_{2} \mathrm{O}_{3}$ & 2.58 & 3.49 & 3.41 & 3.72 & 4.24 & 1.78 & 2.26 & 2.62 & 1.8 & 3.73 \\
\hline $\mathrm{MnO}$ & 0.04 & 0.04 & 0.03 & 0.04 & 0.05 & 0.02 & 0.02 & 0.02 & 0.02 & 0.05 \\
\hline $\mathrm{MgO}$ & 0.48 & 0.89 & 1.32 & 0.94 & 2.11 & 1.01 & 1.08 & 1.02 & 0.95 & 1.55 \\
\hline $\mathrm{CaO}$ & 0.74 & 0.31 & 0.13 & 0.24 & 0.37 & 0.21 & 0.24 & 0.21 & 0.17 & 0.72 \\
\hline $\mathrm{Na}_{2} \mathrm{O}$ & 3.19 & 2.58 & 1.5 & 1.94 & 1.13 & 0.21 & 0.17 & 0.26 & 0.1 & 0.97 \\
\hline $\mathrm{K}_{2} \mathrm{O}$ & 5.31 & 5.27 & 5.51 & 5.05 & 4.95 & 6.35 & 5.48 & 5.94 & 4.19 & 3.98 \\
\hline $\mathrm{P}_{2} \mathrm{O}_{5}$ & 0.11 & 0.13 & 0.08 & 0.09 & 0.07 & 0.11 & 0.12 & 0.11 & 0.10 & 0.09 \\
\hline LOI & 1.14 & 1.85 & 5.09 & 5.41 & 5.34 & 2 & 1.79 & 1.56 & 1.96 & 6.25 \\
\hline $\mathrm{Sc}$ & 6 & 6 & 6 & 5 & 9 & 4 & 5 & 5 & 4 & 8 \\
\hline $\mathrm{Co}$ & 5 & 7 & 7 & 8 & 11 & 4 & 4 & 6 & 4 & 11 \\
\hline $\mathrm{Ni}$ & 13 & 11 & 18 & 17 & 17 & 15 & 12 & 13 & 14 & 21 \\
\hline $\mathrm{Cu}$ & 76 & 30 & 27 & 28 & 31 & 21 & 21 & 23 & 23 & 31 \\
\hline $\mathrm{Th}$ & 52 & 51 & 49 & 51 & 30 & 39 & 39 & 36 & 39 & 24 \\
\hline $\mathrm{Rb}$ & 405 & 323 & 399 & 354 & 303 & 389 & 402 & 411 & 330 & 251 \\
\hline $\mathrm{U}$ & 8 & 6 & 8 & 8 & 6 & 7 & 9 & 9 & 8 & 6 \\
\hline $\mathrm{Sr}$ & 41 & 41 & 32 & 42 & 40 & 11 & 7 & 12 & 1 & 43 \\
\hline $\mathrm{Y}$ & 41 & 41 & 45 & 48 & 29 & 56 & 19 & 32 & 38 & 36 \\
\hline $\mathrm{Zr}$ & 122 & 167 & 130 & 144 & 148 & 97 & 128 & 127 & 120 & 143 \\
\hline $\mathrm{Nb}$ & 16 & 22 & 17 & 18 & 17 & 15 & 18 & 18 & 15 & 14 \\
\hline $\mathrm{La}$ & 47.3 & 57.86 & 53.53 & 55.2 & 38.96 & 27.39 & 13.80 & 25.33 & 50.23 & 41.19 \\
\hline $\mathrm{Ce}$ & 99.1 & 121.01 & 108.22 & 105.4 & 76.95 & 56.92 & 28.56 & 52.54 & 102.25 & 82.83 \\
\hline $\operatorname{Pr}$ & 9.99 & 11.81 & 11.06 & 12.8 & 7.82 & 5.82 & 3.18 & 5.33 & 10.39 & 8.21 \\
\hline $\mathrm{Nd}$ & 39.54 & 46.44 & 45.34 & 48.70 & 31.51 & 25.45 & 13.62 & 21.42 & 40.02 & 33.47 \\
\hline $\mathrm{Sm}$ & 8.14 & 9.48 & 9.56 & 10.55 & 6.16 & 5.76 & 3.00 & 4.69 & 7.79 & 6.79 \\
\hline $\mathrm{Eu}$ & 1.54 & 1.78 & 1.76 & 0.48 & 1.18 & 1.23 & 0.64 & 0.90 & 1.34 & 1.31 \\
\hline $\mathrm{Gd}$ & 7.83 & 8.89 & 8.69 & 8.23 & 5.34 & 8.27 & 3.34 & 4.80 & 6.33 & 5.96 \\
\hline $\mathrm{Tb}$ & 1.35 & 1.47 & 1.50 & 1.40 & 0.88 & 1.50 & 0.61 & 0.86 & 1.03 & 1.01 \\
\hline Dy & 8.69 & 8.63 & 8.67 & 8.82 & 5.08 & 11.95 & 4.42 & 6.21 & 6.16 & 5.99 \\
\hline Ho & 1.67 & 1.55 & 1.52 & 1.44 & 0.94 & 2.20 & 0.85 & 1.19 & 1.11 & 1.06 \\
\hline Er & 4.77 & 4.29 & 4.29 & 3.32 & 2.77 & 6.30 & 2.48 & 3.37 & 3.16 & 3.01 \\
\hline $\mathrm{Tm}$ & 0.66 & 0.56 & 0.58 & 0.43 & 0.38 & 0.88 & 0.36 & 0.48 & 0.42 & 0.43 \\
\hline $\mathrm{Yb}$ & 3.54 & 2.85 & 3.03 & 2.51 & 2.11 & 4.38 & 1.94 & 2.58 & 2.15 & 2.30 \\
\hline $\mathrm{Lu}$ & 0.50 & 0.43 & 0.40 & 0.36 & 0.35 & 0.53 & 0.26 & 0.35 & 0.32 & 0.30 \\
\hline CIA & 49.73 & 53.70 & 65.63 & 62.27 & 65.56 & 64.03 & 66.80 & 64.30 & 71.87 & 65.08 \\
\hline CIW & 64.94 & 71.72 & 85.96 & 80.54 & 85.58 & 94.90 & 95.71 & 93.61 & 97.30 & 82.23 \\
\hline PIA & 49.50 & 57.43 & 79.65 & 72.46 & 79.24 & 90.15 & 91.42 & 89.32 & 94.70 & 75.87 \\
\hline
\end{tabular}

\subsection{Major oxides}

\subsubsection{WPa profile}

In WPa profile (figure $3 \mathrm{a}$ ), $\mathrm{SiO}_{2}$ varies from $73.80-$ $64.42 \mathrm{wt} \%$ and is drastically depleted from LAR to regolith layer. $\mathrm{Al}_{2} \mathrm{O}_{3}$ and $\mathrm{TiO}_{2}$ are showing a negative correlation with $\mathrm{Si} ; \mathrm{Al}_{2} \mathrm{O}_{3}$ varying from 12.2 to $15.0 \mathrm{wt} \% ; \mathrm{TiO}_{2}$ is ranging between 0.3 and $0.6 \mathrm{wt} \% . \mathrm{Fe}_{2} \mathrm{O}_{3}$ shows enrichment (2.58-4, 24 wt\%), similar to $\mathrm{TiO}_{2}$. General depletion of highly mobile elements like $\mathrm{Ca}, \mathrm{Na}$ and $\mathrm{P}$ are observed relative to LAR. The $\mathrm{MgO}$ concentration is enhancing from LAR to regolith. The overall enrichment of potash is observed (attested by the presence of microcline and orthoclase) but not much variation is noticed from LAR to regolith (5.31 to $4.95 \mathrm{wt} \%)$.

\subsubsection{WPb profile}

In $\mathrm{WPb}$ profile, major oxides (figure $3 \mathrm{~b}$ ) show variation at $0.4-4.6 \mathrm{wt} \%$ as a function of extent of weathering from the LAR to top soil. Silica is behaving much differently from WPa profile as it shows alternate enrichment and depletion. However, immobile elements like $\mathrm{Ti}, \mathrm{Al}$ and $\mathrm{Fe}$ show 


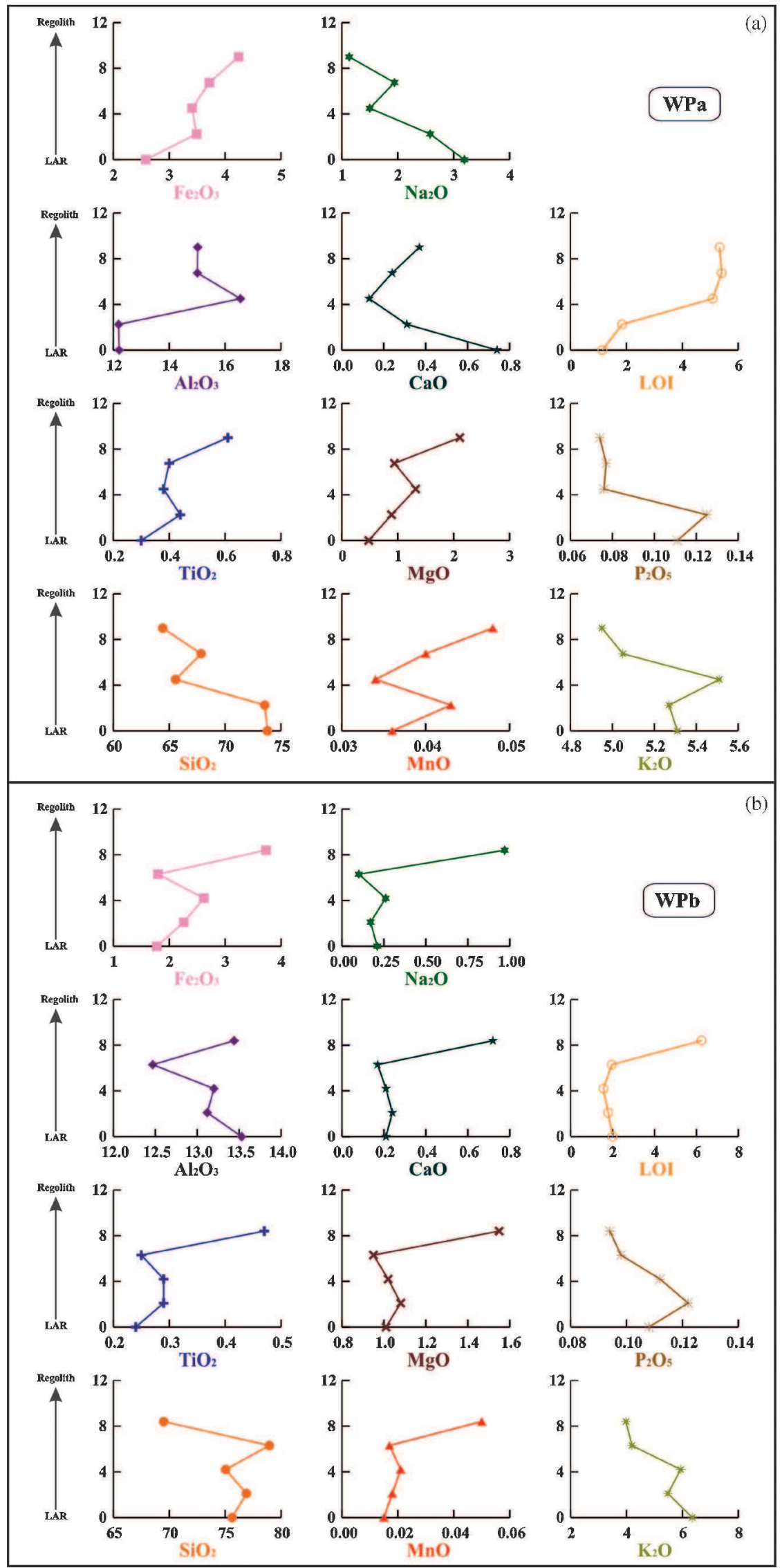

Figure 3. (a) Binary plots of major oxides (in wt\%) of (a) WPa profile and (b) WPb profile, Alaknanda valley. (LAR represents least altered rock.) 
identical behaviour. Elements such as $\mathrm{Ca}, \mathrm{Na}$ and $\mathrm{Mg}$ show depletion up to saprolite relative to LAR but $\mathrm{K}$ depletes all through. Both the profiles show distinct enhancement in the LOI indicating the increase in water content in the sample with progressive weathering. Although it cannot ascertain the standard behaviour of elements in any of the zones, however in general, enhancement of $\mathrm{Al}, \mathrm{Fe}$ and $\mathrm{Ti}$ are noticed in regolith of both the profiles.

\subsection{Trace elements}

\subsubsection{WPa profile}

Recurring enrichment and depletion in the behaviour of the trace elements are observed in the WPa profile (figure 4a). Large ion lithophile element (LILE) like $\mathrm{Rb}$ and $\mathrm{Sr}$ are mobile and it behaves similar to $\mathrm{K}$ and $\mathrm{Ca}$. $\mathrm{Rb}$ shows distinct depletion (404-302 ppm) but $\mathrm{Sr}$ is depleted in saprolithic zone (32 ppm). K-feldspar contains more $\mathrm{Rb}$ than biotite and is easily weathered. Transition elements like $\mathrm{Co}, \mathrm{Ni}$, Sc show enhancement (Co: 5-17 ppm; Ni: 13-17 ppm and Sc: 6-9 ppm). High field strength elements (HFSE) like Y, which exhibits enhancement from LAR to saprolite (41$48 \mathrm{ppm}$ ), however depletes in regolith (29 ppm); whereas Zr initially enriched in saprock (167 ppm), further depleted in other zones (130-148 ppm). Distinct depletion is also noticed in Th and $\mathrm{U}$ (Th: 52-29 ppm and U: 7-6 ppm).

\subsubsection{WPb profile}

In general, $\mathrm{Rb}$ is depleted from the LAR to regolith but in saprock and saprolith, it has an enhancing trend. However, Sr is enriched from base to top. Y and $\mathrm{Zr}$ do not show similar behaviour as WPa profile, i.e., Y shows overall depletion from the LAR to the regolith (55-36 ppm); Zr exhibits continuous enhancing trend from the LAR to regolith (97-143 ppm) (figure 4b). Th and U are depleted from LAR to regolith (Th: 39-24 ppm; U: 7-6 ppm). Co, Ni, Sc are enriched relative to LAR (Co: 4-11 ppm; Ni: 15-21 ppm; Sc: 4-8 ppm).

\subsection{Rare earth elements (REE)}

In general, it is believed that REE are the most robust elements to any change and are resistant to fractionation in supracrustal environment (Nesbitt 1979). However, recent studies show mobility of these elements during chemical alterations. The REE data of the individual elements were normalized with chondrite value of Sun and McDonough (1989) in order to have a close approximation to cosmic abundances of these elements. This procedure in a way brings out the degree of fractionation from a primordial distribution pattern and smooth out the odd-even (zigzag) pattern of absolute REE abundances (Mason and Moore 1982). The REE data of both the weathered profiles of gneissic rocks are presented in table $1(\mathrm{a}$ and $\mathrm{b})$.

\subsubsection{WPa profile}

Considerable amount of mobility of REE concentration is observed in $\mathrm{WPa}$ profile (figure 5a). The general behaviour of REE shows enriched steep LREE (Light Rare Earth Element) and moderately depleted HREE (Heavy Rare Earth Element) pattern. Eu and Ce are the elements among REEs which are very prone to changes because of its variable oxidation states. The significant negative $\mathrm{Eu}$ anomaly with respect to neighbouring elements such as Sm and Gd is due to the fractional crystallization of plagioclase feldspar as it hosts. The fractionation of REE in the weathered profile has started in the early stages of weathering. However, effects of weathering on the distribution patterns of REE became apparent only at the advanced stages of weathering, where the REE abundances increased systematically as the intensity of weathering increased (Aydin and Aydin 2009). In WPa profile, enrichment of LREE and depletion of HREE in saprock, saprolith, saprolite and regolith with reference to LAR is noticed. The presence of good amount of accessory minerals like monazite, allanite and apatite may be responsible for the enrichment of LREE and MREE (Middle Rare Earth Element).

\subsubsection{WPb profile}

In $\mathrm{WPb}$ profile, LREE exhibits steep enriched pattern and moderate to flat depleted HREE pattern as shown in figure 5(b). Distinct negative $\mathrm{Eu}$ anomaly throughout the profile supports the signature of plagioclase fractionation. This fact conclusively shows that the negative Eu anomaly can be produced during chemical weathering of granitic rocks (Condie et al. 1995). Enrichment of LREE in saprolite and regolith and depletion in both saprock and saprolith relative to LAR are observed. However, the depletion of HREE from LAR to the regolith is noticed. The depletion of LREE in saprock and saprolith may be due to leaching. The continuous depletion pattern of HREE may be attributed to the mobility of zircon during the weathering process.

\subsection{Chemical index of alteration}

To understand the degree of alteration, Chemical Index of Alteration (CIA) (Nesbitt and Young 


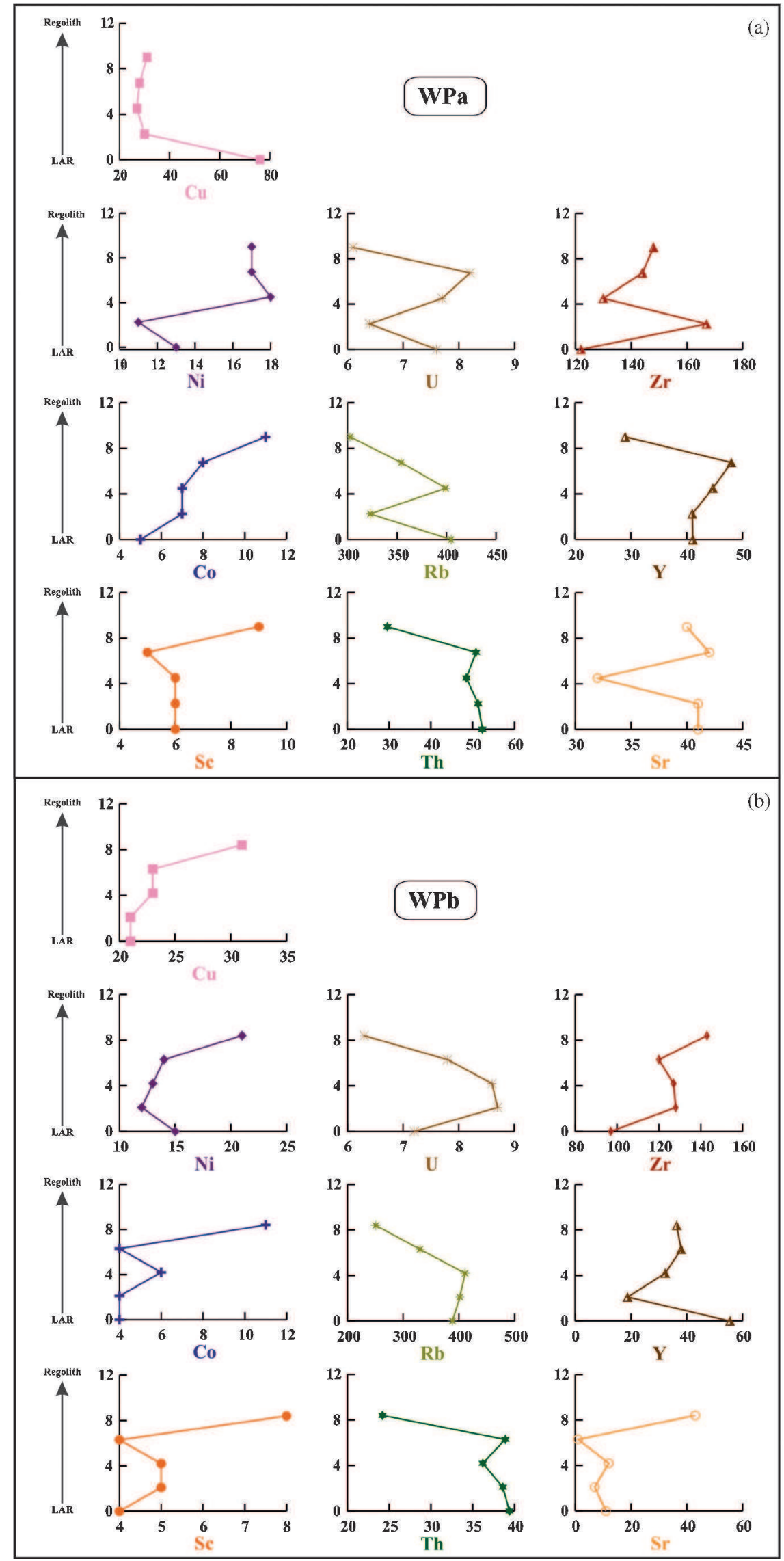

Figure 4. Binary plots of trace elements (in ppm) of (a) WPa profile and (b) WPb profile showing their elemental distribution from LAR to regolith. 


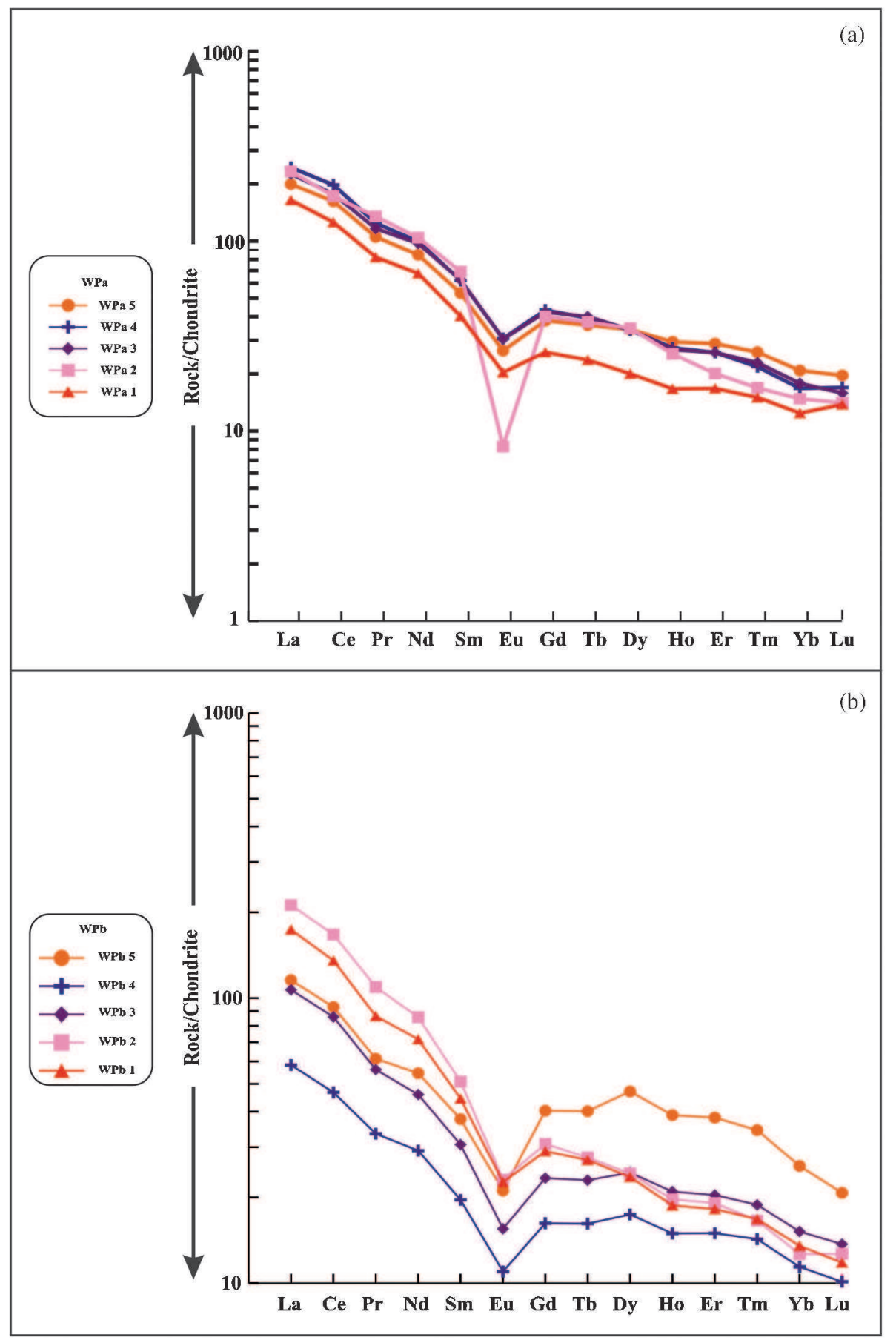

Figure 5. Chondrite normalized REE pattern of (a) WPa profile and (b) WPb profile developed on granite gneisses. Normalized values are after Sun and McDonough (1989).

$1982,1984,1989)$ is calculated. CIA is used in a molar proportion of the sediments, quantitatively used to measure the extent of chemical weathering. Graphically it is represented in the $\mathrm{A}-\mathrm{CN}-\mathrm{K}$ ternary plot and the empirical formula is

$$
\mathrm{CIA}=\mathrm{Al}_{2} \mathrm{O}_{3} /\left(\mathrm{Al}_{2} \mathrm{O}_{3}+\mathrm{CaO}^{*}+\mathrm{Na}_{2} \mathrm{O}+\mathrm{K}_{2} \mathrm{O}\right) \times 100
$$

The $\mathrm{CaO}^{*}$ is the calcium oxide in the silicate fraction only (McLennan 1993), i.e., Ca is corrected for the rocks and taken from the silicate rocks only.
CIA will give the alteration of the alkaline minerals, viz., $\mathrm{Ca}, \mathrm{Na}$ and $\mathrm{K}$ as it is plotted against the immobile element $\mathrm{Al}$. $\mathrm{A}-\mathrm{CN}-\mathrm{K}$ plots provide insight into the weathering trends and tectonoclimatic milieu in the source region (Nesbitt and Young 1982, 1984). In an A-CN-K diagram, a typical weathering trend will be originating from the source rock composition and is parallel to $\mathrm{A}-\mathrm{CN}$ tie line. The calculations were done in molecular proportion, on a carbonate free basis (McLennan 
1993; Bock et al. 1998). In the $\mathrm{A}-\mathrm{CN}-\mathrm{K}$ plot of WPa profile, the LAR is plotting on or near the plagioclase tie line, i.e., 50 and its values go up to 65 (figure 6a), i.e., in regolith. Whereas CIA value of LAR of $\mathrm{WPb}$ is 64 and 65 in regolith (figure $6 \mathrm{~b}$ ), in which a negligible difference is observed in the profile. However, the highest CIA value is observed in saprolitic layer (71) of WPb profile and this is due to the accumulation of alkali elements relative to immobile element $\mathrm{Al}$.

\subsection{Relative mobility}

To understand the elemental mobility in individual profile, the percentage change of individual

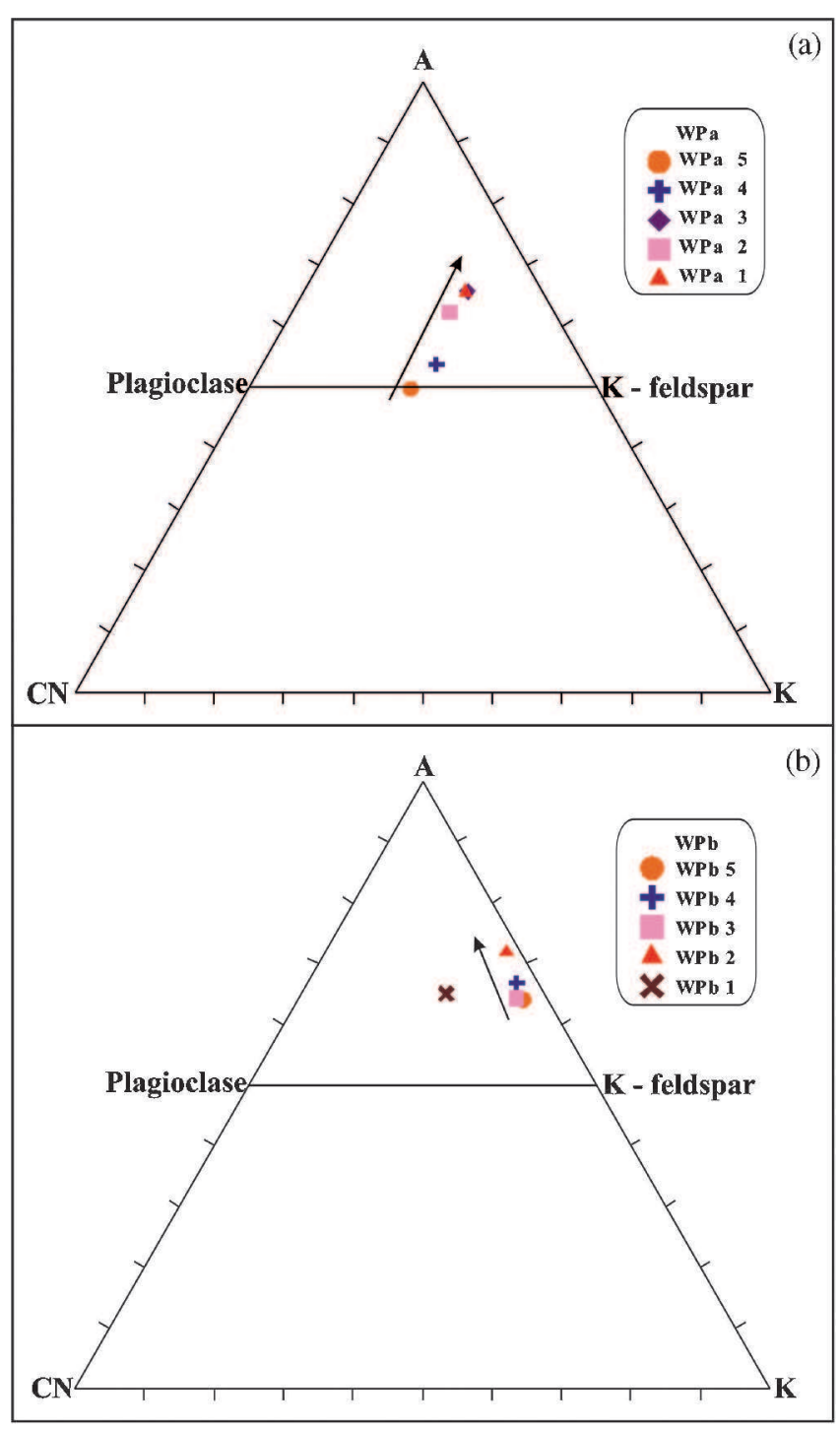

Figure 6. (a) $\mathrm{A}-\mathrm{CN}-\mathrm{K}\left(\mathrm{A}=\mathrm{Al}_{2} \mathrm{O}_{3}, \mathrm{CN}=\mathrm{CaO}^{*}+\mathrm{Na}_{2} \mathrm{O}, \mathrm{K}=\right.$ $\mathrm{K}_{2} \mathrm{O}$ ) ternary plot of $\mathrm{WPa}$ profile, Alaknanda valley. The calculated values are in molecular proportion. (b) $\mathrm{A}-\mathrm{CN}-\mathrm{K}$ $\left(\mathrm{A}=\mathrm{Al}_{2} \mathrm{O}_{3}, \mathrm{CN}=\mathrm{CaO}^{*}+\mathrm{Na}_{2} \mathrm{O}, \mathrm{K}=\mathrm{K}_{2} \mathrm{O}\right)$ ternary plot of $\mathrm{WPb}$ profile, Alaknanda valley. The calculated values are in molecular proportion. elements relative to LAR is calculated using the formula proposed by Nesbitt (1979) and is given as:

$$
\% \text { Change }=\left[\left(X^{\mathrm{s}} / I^{\mathrm{s}}\right) /\left(X^{\mathrm{p}} / I^{\mathrm{p}}\right)-1\right] \times 100
$$

where $X^{\mathrm{s}}$ is the element in the sample, $X^{\mathrm{p}}$ is element in the parent rock, $I^{\mathrm{s}}$ is immobile element in the sample and $I^{\mathrm{p}}$ the immobile element in the parent. Zircon is considered to be a very resistant mineral and is mostly present in the sediments. It is stable during weathering that lead to exceptionally low solubility in aqueous solutions. Zircon is also present in the granitic rock which is very stable to any alteration taking place significantly during weathering. However, it is not uniformly distributed in all the samples. Therefore zirconium may introduce significant inter-sample error when calculating the percentage change of other elements. Hence, $\mathrm{TiO}_{2}$ is considered as an immobile component and the percentage change is calculated with respect to $\mathrm{TiO}_{2}\left(I^{\mathrm{s}}\right.$ and $I^{\mathrm{p}}$ ) (Nesbitt 1979). However, studied profiles of Garhwal Lesser Himalaya show the mobility of $\mathrm{TiO}_{2}$ (concentration of $\mathrm{TiO}_{2}$ in regolith is almost double of LAR in both the profiles). Therefore in place of percentage change, the relative mobility (RM) of an element with respect to LAR is calculated as suggested by Rajamani et al. (2009),

$$
R M=\left((X i)^{\mathrm{s}} /(X i)^{\mathrm{p}}-1\right) \times 100
$$

where $(X i)^{\mathrm{s}}$ and $(X i)^{\mathrm{p}}$ are the concentrations of the $i$ th component in the sample and parent, respectively.

In order to understand the mobility and behaviour of individual major and trace elements during weathering, the relative mobility of each major and trace element was plotted with respect to the LAR. RM of major elements of individual profile is calculated and is described below.

\subsubsection{Relative mobility of major elements}

In WPa section, considerable amount of depletion is observed in the $\mathrm{Ca}, \mathrm{Na}$ and $\mathrm{Si}$. In saprock, $\mathrm{P}$ shows little enhancement whereas in successive layers it is depleted. Among the other major elements, viz., $\mathrm{Mg}, \mathrm{Ti}, \mathrm{Fe}$ and $\mathrm{Al}$ show considerable enrichment, however $\mathrm{Mg}$ enrichment in regolith is drastic in terms of relative mobility. $\mathrm{Ti}, \mathrm{Fe}$ and $\mathrm{Mn}$ also show enrichment in the regolith (figure 7a). Whereas in relative mobility (RM) plot of $\mathrm{WPb}$ section, enhancement of $\mathrm{Fe}, \mathrm{Mn}, \mathrm{Ti}, \mathrm{Mg}$ are noticed but $\mathrm{K}, \mathrm{Ca}$ and $\mathrm{Si}$ show depletion (figure $7 \mathrm{~b}$ ). Despite, negative correlation between $\mathrm{Al}$ and $\mathrm{Si}, \mathrm{Al}$ shows depletion in saprock and enrichment in the regolith. The depletion of $\mathrm{Na}$ in the saprock and saprolite is also observed and enrichment is noticed in saprolith and regolith. Significant enrichments 


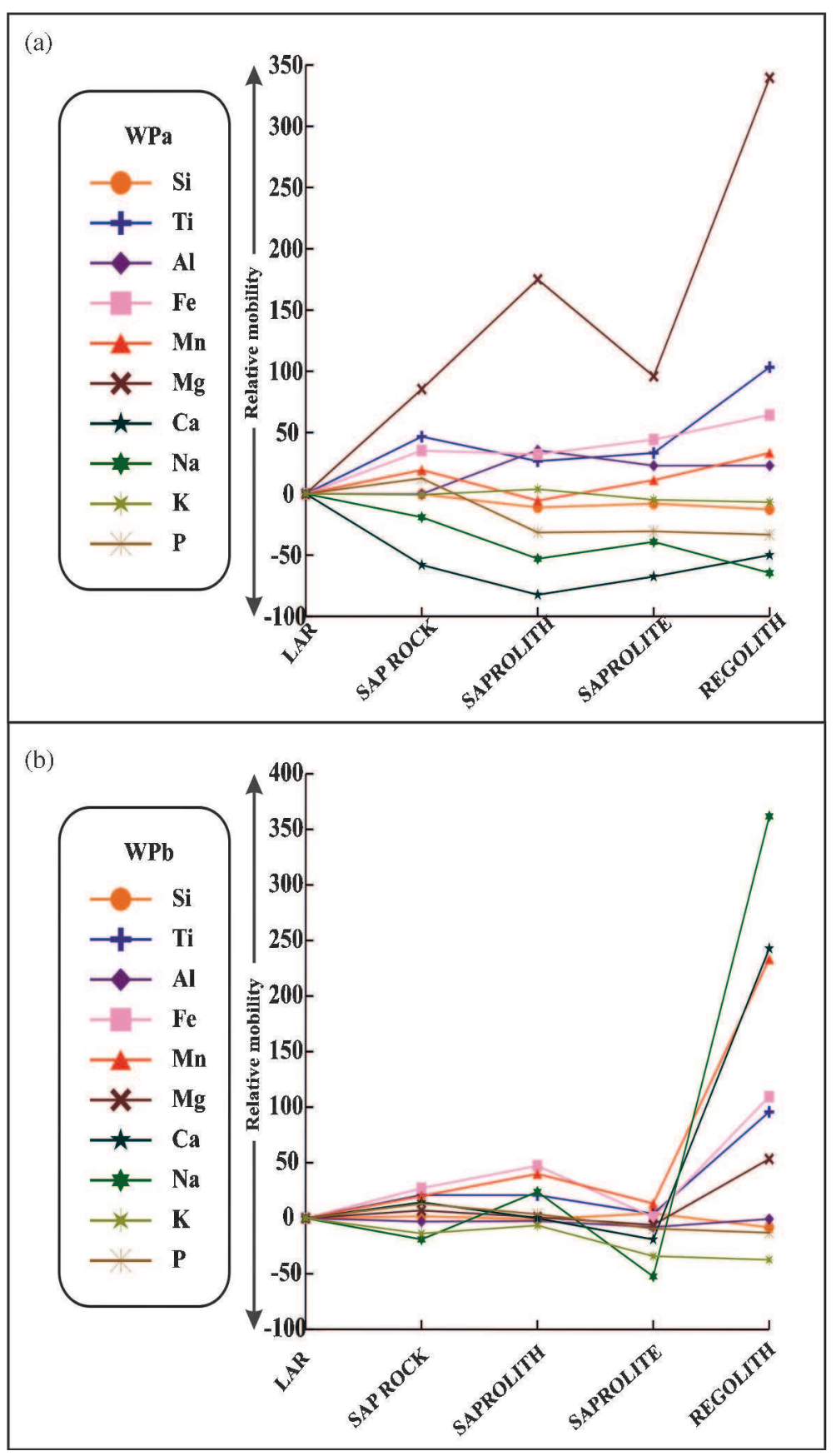

Figure 7. Relative mobility of major oxides in (a) WPa profile and (b) WPb profile, Alaknanda valley. (Samples are arranged from LAR to regolith.)

are observed in $\mathrm{Na}, \mathrm{Ca}, \mathrm{Mn}, \mathrm{Fe}, \mathrm{Ti}$ and $\mathrm{Mg}$ in regolith layer.

\subsubsection{Relative mobility of trace elements}

Relative mobility of trace elements is also calculated and shown in binary plot. The trace elements were grouped into LILE (large ion lithophile element), HFSE (high field strength element) and TTE (transition trace element) and are plotted separately in individual profiles.
In WPa profile, drastic depletion of LILEs like $\mathrm{Rb}, \mathrm{U}$ is noticed in the saprock and regolith, whereas enhancement is observed in saprolith and saprolite (figure 8a). Sr is depleted in saprolith and shows enrichment in saprolite. However, in $\mathrm{WPb}$ profile, enhancement is observed in $\mathrm{Rb}$ and $\mathrm{U}$ in saprock, saprolith and saprolite but show depletion in the regolith relative to the LAR. Th shows depletion throughout the profile and Sr shows erratic behaviour in saprock, saprolith and saprolite but enhancement is observed in regolith (figure 9a). 


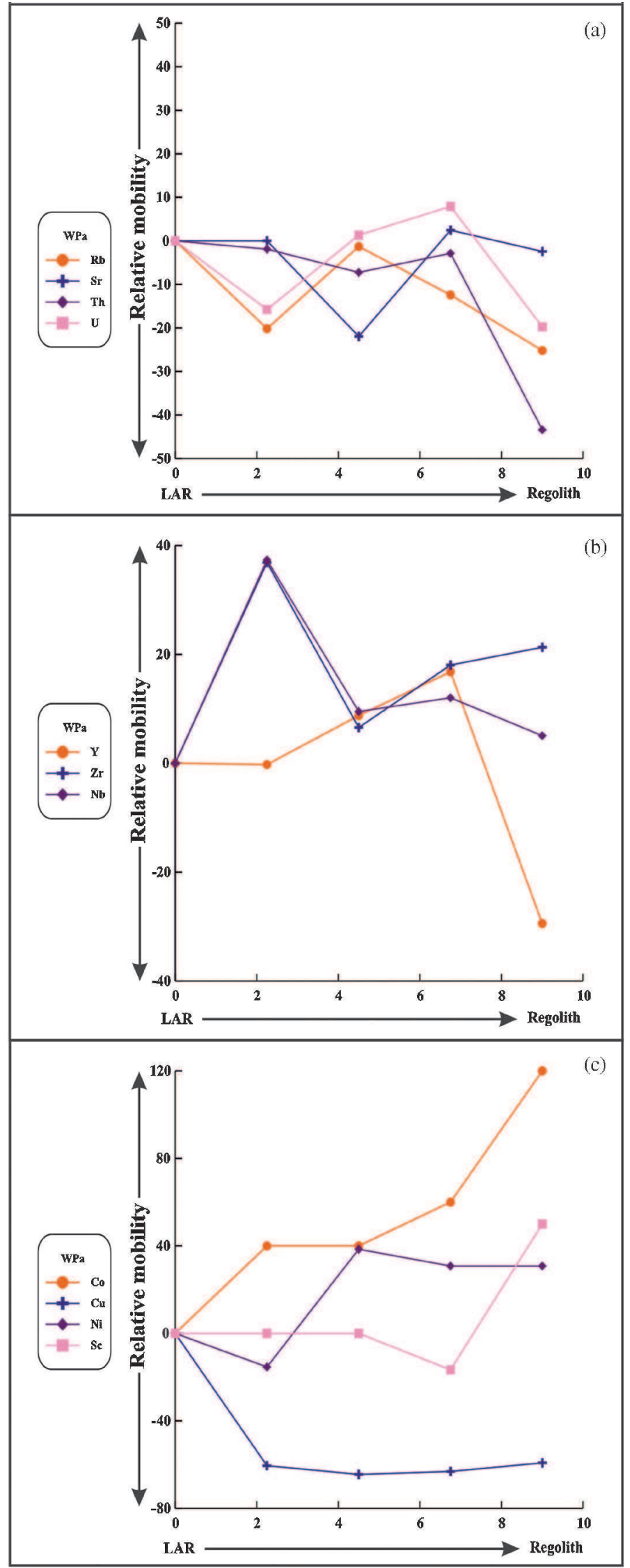

Figure 8. (a) Relative mobility of trace elements (LILE) of (a) WPa profile, Alaknanda valley. (b) Relative mobility of trace elements (HFSE) of WPa profile, Alaknanda valley. (c) Relative mobility of transition trace elements (TTE) of WPa profile, Alaknanda valley. (Samples are arranged from LAR to regolith.) 


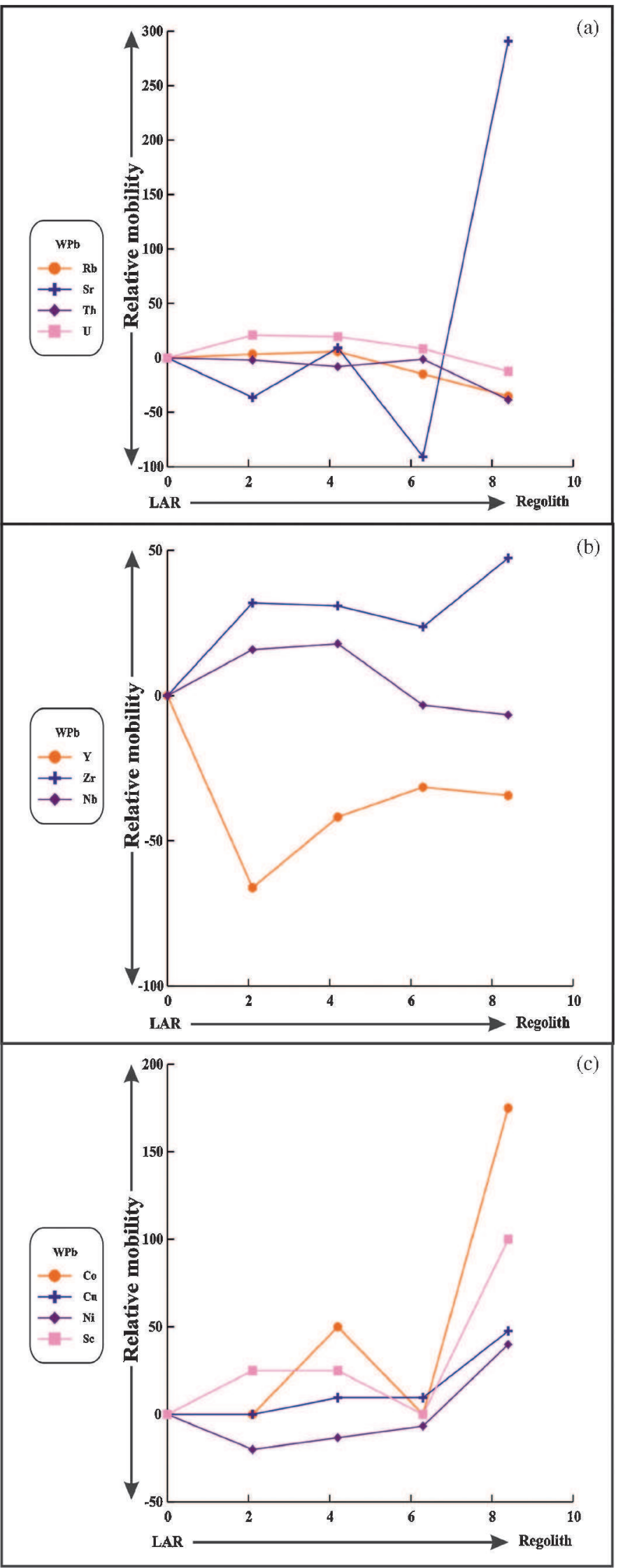

Figure 9. (a) Relative mobility of trace elements (LILE) of WPb section, Alaknanda valley. (b) Relative mobility of trace elements (HFSE) of WPb profile, Alaknanda valley. (c) Relative mobility of transition trace elements (TTE) of WPb profile, Alaknanda valley. (Samples are arranged from LAR to regolith.) 
Among the HFSE, Zr and Nb show enrichment in the saprock and regolith, however depletion of Y is observed in saprock and regolith layers of $\mathrm{WPa}$ profile (figure $8 \mathrm{~b}$ ). In $\mathrm{WPb}$ profile, in terms of relative mobility, $\mathrm{Zr}$ and $\mathrm{Nb}$ show enrichment from LAR to regolith but significant depletion of $\mathrm{Y}$ is noticed all through the profile (figure $9 \mathrm{~b}$ ).

In WPa profile, enrichment is observed in TTE like $\mathrm{Co}$ and $\mathrm{Ni}$ except a depletion kink in $\mathrm{Ni}$ in saprock. Sc almost maintained its conserved pattern in all the layers of the profile except enrichment in regolith. Distinct depletion pattern of $\mathrm{Cu}$ is observed throughout the profile (figure 8c). Whereas in $\mathrm{WPb}$ profile, Sc shows enhancement in the saprock, saprolith; and depletion in the saprolite layer, but again a drastic enrichment is observed in the regolith relative to LAR. Ni shows depletion in all the layers but enhancement is observed in regolith. Co shows depletion in the saprock and saprolite but is drastically enhanced in saprolith and regolith. Depletion of $\mathrm{Cu}$ is observed in the entire profile except enrichment in the regolith (figure 9c).

\section{Discussion}

Himalaya is a dynamic mountain range and has a complex geological set-up. This tectonically active mountain range, exhibits diverse topographical architecture which leads to the manifestation like variation of precipitation in the region, and therefore climatic difference and disparity in the $\mathrm{CO}_{2}$ consumption that provide divergence in weathering, elemental mobility and vegetation. The study area is located in the Lesser Himalayan terrain and is ideal for understanding discrepancy in the vibrant weathering and the area also receives higher precipitation as compared to Higher Himalaya and this is due to altitudinal differences. The weathering and erosion leads to the development of very fertile land between the mountain front and ocean, i.e., Indo-Gangetic plain.

Lithologically, Lesser Himalaya is covered by gneiss, schist, quartzite and basic volcanic rocks. Amongst this, gneiss is one of the most prominent rock types of the region and is mostly granitic in composition. These granites are crystallized in the deep, beneath the earth and are exposed to the earth's surface after repeated erosion and upliftment due to tectonic activities. As soon as it is exposed to the surface climatic conditions, the rock will be under disequilibrium and will achieve its equilibrium state through the process of weathering. These gneisses exhibit numerous features such as foliation, lineation, folds and weak planes like thrusting, shearing, fractures, etc. These structural features (like foliation, lineation) are easy passage for water percolation and penetration. Therefore gneissic rocks are more prone to weathering because of their distinct mineralogy especially feldspar and mica which are more susceptible to the weathering. In our studied profiles, porphyry granite gneiss and granite gneiss show the diversification in the dissolution of minerals during the progressive weathering processes due to the variable textures. These weathered profiles are developed at the vicinity of thrust and faults which further activate the physical weathering processes followed by chemical weathering due to infiltration of precipitated water in minor and major cracks developed during physical weathering.

The geochemical study carried out included major, trace and rare earth elements as a main proxy for the gneissic rocks of Lesser Himalayan region to understand the chemical weathering processes in subtropical humid climate. Based on our field observations, the studied weathered profiles (WPa and $\mathrm{WPb}$ ) belong to the grade IV category (Ehlen 2005) and contain thin soil layer at the top of the profile. The soils which are thinly formed on the granite gneissic terrain contain rich weatherable minerals that favour the chemical weathering. However, thickly covered soil reduces the primary minerals and minimizes chemical weathering (Oliva et al. 2003). The regolith layer (soil layer) of $\mathrm{WPa}$ and $\mathrm{WPb}$ profiles consists of very low clay content. This indicates that the degree of physical weathering is very significant without much chemical alteration (Sharma and Rajamani 2000). Physical weathering plays a vital role for the formation of joints and fractures; and the higher intensity in the fracture speed up chemical weathering rate, hence higher alteration of the minerals.

The rain water plays a major role in the chemical alteration by the consumption of $\mathrm{CO}_{2}$ in the area. Precipitation is acidic in nature and enhances the acidity of the rock. In the weathering mantle, the feldspars are being attacked first as these minerals are hosting mobile elements such as $\mathrm{Na}, \mathrm{Ca}, \mathrm{K}$, etc., therefore there is noteworthy depletion of these elements. $\mathrm{Na}$ and $\mathrm{Ca}$ mobility is more than $\mathrm{K}$ in the $\mathrm{WPa}$ profile (figure 3a) because of more plagioclase alteration than K-feldspar (Middelburg et al. 1988) and $\mathrm{K}$ is less mobile relative to other more labile elements like $\mathrm{Na}$ and $\mathrm{Ca}$. In the $\mathrm{WPb}$ profile, little/negligible mobility is observed in $\mathrm{Na}$ and $\mathrm{Ca}$ from LAR to saprolitic layer. However, drastic enhancements of these elements are observed in regolithic layer. This is due to the accumulation of $\mathrm{Na}$ and $\mathrm{Ca}$ in regolith supplied by organic matter from the adjoining region. The depletion of $\mathrm{K}$ from the LAR to the regolith is significant $(6.35-3.98 \mathrm{wt} \%$ ) (figure $3 \mathrm{~b}$ ) and this may be due to higher alteration of $\mathrm{K}$ feldspar, hence leaching. $\mathrm{P}_{2} \mathrm{O}_{5}$ is decreasing from 
$\mathrm{LAR}$ to regolith in both $\mathrm{WPa}$ and $\mathrm{WPb}$ profiles (figure $3 \mathrm{a}, \mathrm{b}$ ) and the alteration of apatite is responsible for the depletion of phosphorus (as apatite hosts P) which is very prone to weathering (Rice 1973). Ti and Fe are enhancing in the weathered mantle from LAR to regolith (figure $7 \mathrm{a}, \mathrm{b}$ ). These elements are relatively immobile during weathering processes and this phenomena is quite prominent in $\mathrm{WPb}$ profile, but $\mathrm{Si}$ and $\mathrm{Al}$ show (figure 7b) decreasing trend from the LAR to most altered layer (regolith), however, both show antipathic relation. LOI is also enhanced in both $\mathrm{WPa}$ and $\mathrm{WPb}$ profiles during progressive weathering (figure $3 \mathrm{a}, \mathrm{b}$ ). This indicates that the area receives more precipitation which penetrates the weak zones (like fractures) and enhance chemical weathering in the profiles. Therefore, we attribute that the lithology plays a vital role for the alteration processes, hence the disparity in the nature of elemental behaviour.

Among the trace elements, Rb behaves similar to potassium during crystallization of magmas and also during water-rock interaction because of their same valency $(+1)$ and almost similar ionic radii (1.38 for $\mathrm{K} ; 1.52$ for $\mathrm{Rb}$ ). In $\mathrm{WPa}$ and $\mathrm{WPb}$ profiles, similar behaviour of $\mathrm{K}$ and $\mathrm{Rb}$ is observed. In the same way, $\mathrm{Sr}$ also behaves much similar to $\mathrm{Ca}$; $\mathrm{Sr}$ decreases with the increase in alteration of rock (figure $4 \mathrm{a}$ ). Because of the atomic size, $\mathrm{Sr}$ depletes more readily than Ca (Middelburg et al. 1988). Likewise $\mathrm{Zr}, \mathrm{Nb}$, and Sc (figure 4a,b) are immobile elements. However, mobility is observed (zig-zag behaviour) and this is due to change in Eh- $\mathrm{pH}$ conditions during weathering. Further, $\mathrm{Cu}$ is also mobilized with the increase of alteration, as major portion of these elements are housed in biotite mica, which is more prone to weathering.

Weathering processes generate sediments via physical and chemical processes. The extent of weathering is controlled by the climate and tectonic conditions in the source rock and defines the nature of the sediments. The key weathering process in the Himalaya is the physical weathering. This is due to high relief, which does not affect the original CIA of the rocks (Srivastava et al. 2008). CIA is the source to understand the alteration of highly mobile elements (Na, Ca, K) relative to immobile element $(\mathrm{Al})$ and is represented graphically in a ternary plot ( $\mathrm{A}-\mathrm{CN}-\mathrm{K}$ projection) for better understanding of the intensity of weathering. CIA of LAR (50) of WPa profile is plotting on a feldspar tie line showing its unweathered nature. The other, saprock (54), saprolith (66), saprolite (62) and regolith (66) layers show increase in CIA value with the advancement of weathering. But in $\mathrm{WPb}$ profile, the LAR itself is plotting close to $\mathrm{A}-\mathrm{K}$ join and have a higher CIA value (64), which may be due to the $\mathrm{K}$ metasomatism in the rock during the conversion of gneisses from granitic rocks; and higher value attributed to the moderate weathering during the uplift. The successive saprock (67), saprolith (64), saprolite (72) and regolith (65) show moderate weathering but the weathering trend remains parallel to $\mathrm{A}-\mathrm{K}$ tie line. Higher value in saprolite is due to consumption of higher rain water that lead to water-rock interaction, hence higher CIA value. But the sample of regolithic layer is plotting away from the $\mathrm{A}-\mathrm{K}$ tie line, this may be due to the addition of $\mathrm{Ca}$ and $\mathrm{Na}$ from the biogenic source. To understand the enriched nature of $\mathrm{K}$ in gneissic rock, we employed CIW (chemical index of weathering) of Harnois (1988) and Maynard (1992). The CIW is similar to CIA except for the absence of $\mathrm{K}_{2} \mathrm{O}$ and is empirically presented as:

$$
\mathrm{CIW}=\mathrm{Al}_{2} \mathrm{O}_{3} /\left(\mathrm{Al}_{2} \mathrm{O}_{3}+\mathrm{CaO}^{*}+\mathrm{Na}_{2} \mathrm{O}\right) \times 100 .
$$

The CIW value is ranging from 64 (LAR) to 85 (regolith) in WPa profile and 94 (LAR) to 82 (regolith) in WPb profile. However, the CIW is 97 in the saprolite layer of WPb profile. The higher CIW value in the studied profile is due to the absence of $\mathrm{K}_{2} \mathrm{O}$ in the equation which explains the gneissic rocks that have undergone $\mathrm{K}$ metasomatism prior to weathering. The proximity of $\mathrm{WPb}$ profile to Ramgarh Thrust is also responsible for the addition of $\mathrm{K}$ during the movement.

Based on these studies it is confirmed that the lithology with lower potassium contents weathers faster than the lithology with higher potassium. Therefore we suggest that porphyritic nature of $\mathrm{WPa}$ profile has restricted the enhancement of CIW and PIA values whereas non-porphyritic nature of $\mathrm{WPb}$ profile leads to the enhancement of all the alteration indices.

Many studies have been carried out to understand REE remobilization and redistribution during weathering (Nesbitt 1979; Middelburg et al. 1988; Rajamani et al. 2009 and others). However, there is great debate regarding their mobilization. Middelburg et al. (1988) reports the REE fractionation during the advanced stages of weathering, whereas Price et al. (1991) suggested that the most drastic REE fractionation takes place during the early stages. In general, none of the primary minerals are rich in REE content. Except quartz and Kfeldspar, other primary minerals, particularly plagioclases, are not resistant to weathering and are pseudomorphically replaced by secondary phases (dominantly clay minerals) at the early stages of weathering (Aydin et al. 2002). This may explain visually obvious and immediate effects of weathering processes on the textural and mineralogical characteristics of the moderately decomposed sample. WPa weathered profile show fractionation of total REE in the last stages of weathering (i.e., 
in regolithic layer). However, in $\mathrm{WPb}$ profile $\mathrm{REE}$ fractionation is observed in the initial stages, i.e., in saprock and saprolth, but enhancement of REE is noticed in the saprolite and regolith. In WPa profile, LREE undergoes progressive enrichment through saprock, saprolith and saprolite; however, HREE are depleted throughout the profile as compared to much enhanced LREE (figure 5a) relative to LAR. Therefore, there is a considerable amount of $\Sigma$ REE removed during the process of alteration but regolithic layer show depletion of both LREE and HREE relative to LAR. In WPb profile (figure 5b), depletion of both LREE as well as HREE is observed compared to LAR throughout the profile. Further, enhancement of HREE is noticed in saprock and is due to the accumulation of zircon. Regolith of $\mathrm{WPb}$ profile is enriched in both LREE as well as HREE. The REE curve of LAR is plotting between saprock and saprolith, especially HREE in WPb profile and this is attributed to the variation in weathering condition. Therefore, we envisage two stages of weathering process occurring in Garhwal Lesser Himalaya; where in an earlier stage, a considerable amount of LREE were added but HREE were selectively removed in a later stage. This indicates that the intensity of weathering enhanced the rare earth elements mobility in this high rainfall area during the last stage of alteration. Mobilization was also controlled by the primary and secondary minerals in addition to Eh and $\mathrm{pH}$ condition in the profile. We envisaged the variation of REE mobility in $\mathrm{WPa}$ and $\mathrm{WPb}$ profiles is due to the lithological control, structural heterogeneities like foliation, lineation and shear zones. This is because of the complex tectonic history of the Himalaya and the quantity of rain water received. Therefore, there is no definite REE mobilization history, i.e., removal and accumulation took place during the weathering process. We suggest that the REE mobilization of granite gneissic weathered profiles of Garhwal Himalaya is independent and the behaviour of REE is not controlled by the weathering processes alone but it is also depending on the nature of the source rock. Smyth (1913); Polynov (1937); Anderson and Hawkes (1958) and Shalkowasky et al. (2008) have defined a different order of elemental mobility in granitic rock. In our study, the elemental mobility also differs in WPa than $\mathrm{WPb}$ weathered profiles due to the amalgamation of variable lithological composition, climate and tectonics of the region. The order of mobility in $\mathrm{WPa}$ profile is $\mathrm{Ca}>\mathrm{Na}>\mathrm{P}>\mathrm{Si}>\mathrm{K}$, whereas the $\mathrm{WPb}$ profile exhibit the order of mobility as $\mathrm{Na}>\mathrm{K}>\mathrm{Ca}>\mathrm{P}>\mathrm{Si}>\mathrm{Al}>\mathrm{Mg}$. Therefore, the above result may infer that the prediction of exact order of elemental mobility is difficult. Further, these chemically altered materials are available in the form of nutrients to the biosphere that are finally transported and deposited in the Indo-Gangetic alluvium plain making it a very fertile land for agriculture through huge Ganga river system.

\section{Conclusions}

The study provides insights on the weathering history of Inner Lesser Himalaya. Two weathered profiles developed on porphyry and non-porphyry granite gneissic lithology were studied in detail and compared for their elemental behaviours. WPa profile shows its protholithic nature in the least altered rock (LAR) exposed on the surface with successive alteration to it; however, WPb shows its chemically altered nature in the LAR with successive alteration in a zig-zag manner. This is due to the strong dependency on the type of lithology followed by tectono-climatic influences that prevailed in the region. Further, the present work also reveals that the REE mobilization took place in both early and advance stages of weathering due to the disparity of lithology followed by climate-tectonic mileu. Therefore, the presence of microclimatic condition is envisaged in the region in broader perspectives. The contrasting behaviour of these profiles developed on early Proterozoic granite rocks of the Lesser Himalaya is due to their exposure to the surface geological processes by periodic upliftment along with erosion in the Himalaya.

\section{Acknowledgements}

The authors thank Prof. A K Gupta, Director, WIHG for providing necessary facilities to carry out this work. They express thanks to Dr Santosh Kumar Rai for helping in field work. They also thank Drs P P Khanna and N K Saini for chemical analysis. Authors are also thankful to the anonymous reviewer for the constructive comments which have greatly improved the manuscript.

\section{References}

Ahmad T, Harris N, Bickle M, Chapman H, Bunbury J and Prince C 2000 Isotopic constraints on the structural relationships between the Lesser Himalayan Series and the High Himalayan Crystalline Series, Garwhal Himalaya; Geol. Soc. Am. Bull. 112 467-477.

Anderson D H and Hawkes H E 1958 Relative solubility of the common elements in the weathering of some schist and granite areas; Geochim. Cosmochim. Acta 14 $204-211$.

Aydin D N S and Aydin A 2009 Distribution of rare earth elements and oxyhydroxide phases within a weathered felsic igneous profile in Hong Kong; J. Asian Earth Sci. 34 1-9. 
Aydin D N S, Aydin A and Malpas J 2002 Re-assessment of chemical weathering indices: Case study from pyroclastic rocks of Hong Kong; Eng. Geol. 63 99-119.

Bock B, McLennan S M and Hanson G N 1998 Geochemistry and provenance of the Middle Ordovician Austin Glen Member (Normanskill Formation) and the Taconian Orogeny in New England; Sedimentology 45 635-655.

Célérier J, Harrison T M, Yin A and Webb A A G 2009 The Kumaun and Garwhal Lesser Himalaya, India. Part 1: Structure and stratigraphy; Geol. Soc. Am. Bull. 121(9/10) 1262-1280.

Chauhan O S, Patil S K and Suneethi J 2004 Fluvial influx and weathering history of the Himalayas since Last Glacial Maxima - isotopic, sedimentological and magnetic records from the Bay of Bengal; Curr. Sci. 87(4) 509-515.

Condie K C, Dengate J and Cullers R L 1995 Behaviour of rare earth elements in a palaeoweathering profile on granodiorite in the Front Range, Colorado, USA; Geochim. Cosmochim. Acta 59 279-274.

DeCelles P G, Robinson D M, Quade J, Ojha T P, Garzione C N, Copeland P and Upreti B N 2001 Stratigraphy, structure, and tectonic evolution of the Himalayan fold-thrust belt in western Nepal; Tectonics 20 487-509.

Dosseto A, Turner S P and Chappell J 2008 The evolution of weathering profiles through time: New insights from uranium-series isotopes; Earth Planet. Sci. Lett. 274 359-371.

Ehlen J 2005 Above the weathering front: Contrasting approaches to the study and classification of weathered mantle; Geomorphology 67 7-21.

Fedo C M, Nesbitt H W and Young G M 1995 Unravelling the effects of potassium metasomatism in sedimentary rocks and paleosols, with implications for paleoweathering conditions and provenance; Geology 23(10) 921-924.

Garrels R M and Mackenzie F T 1971 Evolution of Sedimentary Rocks; W.W. Norton Co., New York.

Goldich S S 1938 A study of rock weathering; J. Geol. 46 17-58.

Grant W H 1963 Weathering of Stone Mountain Granite in Clays and Clay Minerals (ed.) E Ingersol, Pergamon Press.

Harnois L 1988 The CIW index: A new chemical index of weathering; Sedim. Geol. 55 319-322.

Heim A and Gansser A 1939 Central Himalaya: Geological observations of the Swiss Expedition 1936; Memoires de la Société Helvetique des Sciences Naturelles, Zürich, vol. 73, 245p.

Islam R, Ahmad T and Khanna P P 2005 An overview on the granitoids of the NW Himalaya; Him. Geol. 26(1) 49-60.

Islam R, Ghosh S K, Vyshnavi S and Sundriyal Y P 2011 Petrography, geochemistry and regional significance of crystalline klippen in the Garhwal Lesser Himalaya, India; J. Earth Syst. Sci. 120(3) 489-501.

Khanna P P, Saini N K, Mukherjee P K and Purohit K K 2009 An appraisal of ICP-MS technique for determination of REEs: Long term QC assessment of silicate rock analysis; Him. Geol. 30(1) 95-99.

Li G, Ji J, Zhao L, Mao C and Chen J 2008 Response of silicate weathering to monsoon changes on the Chinese Loess Plateau; Catena 72 405-412.

Little M G and Lee C 2006 On the formation of an inverted weathering profile on Mount Kilimanjaro, Tanzania: Buried paleosol or groundwater weathering? Chem. Geol. 235 205-221.

Lucas-Tooth H and Pyne C 1964 Advances in X-ray Analysis; Plenum Press, New York, 7, 523p.

Mason B and Moore C B 1982 Principles of Geochemistry, 4th edn, John Wiley \& Sons, New York, 344p.
Maynard J B 1992 Chemistry of modern soils as a guide to interpreting Precambrian paleosols; J. Geol. 100 279-289.

McLennan S M 1993 Weathering and global denudation; J. Geol. 101 295-303.

Middelburg J J, Van der Weijden C H and Woittiez J R W 1988 Chemical processes affecting the mobility of major, minor and trace elements during weathering of granitic rocks; Chem. Geol. 68 253-273.

Miller C, Klotzli U, Frank W and Thoni M Grasemann B 2000 Proterozoic crustal evolution in the NW Himalaya (India) as recorded by circa $1.80 \mathrm{Ga}$ mafic and $1.84 \mathrm{Ga}$ granitic magmatism; Precamb. Res. 103 191-206.

Nesbitt H W 1979 Mobility and fractionation of rare earth elements during weathering of a granodiorite; Nature $\mathbf{2 7}$ 206-210.

Nesbitt H W and Young G M 1982 Early Proterozoic climates and plate motions inferred from major element chemistry of lutites; Nature 299 715-717.

Nesbitt H W and Young G M 1984 Prediction of some weathering trends of plutonic and volcanic rocks based on thermodynamic and kinetic consideration; Geochim. Cosmochim. Acta 48 1523-1534.

Nesbitt H W and Young G M 1989 Formation and diagenesis of weathering profiles; J. Geol. 97(2) 129-147.

Oliva P, Viers J and Dupre B 2003 Chemical weathering in granitic environments; Chem. Geol. 202 225-256.

Polynov B 1937 The Cycle of Weathering; Murby (English transl.) London, 220p.

Price R G, Gray C M, Wilson R E, Frey F A and Taylor S R 1991 The effects of weathering on rare-earth element, $\mathrm{Y}$ and $\mathrm{Ba}$ abundances in Tertiary basalts from southern Australia; Chem. Geol. 93 245-265.

Purohit K K, Saini N K and Khanna P P 2010 Geochimical dispersion pattern of heavy metal abundances in the intermontane Pinjaur Dun, SubHimalaya; Him. Geol. 31(1) 29-34.

Rajamani V, Tripathi J K and Malviya V P 2009 Weathering of lower crustal rocks in the Kaveri river catchment, southern India: Implications to sediment geochemistry; Chem. Geol. 265 10-419.

Rice C M 1973 Chemical weathering on the Carnmenellis granite; Mineral Mag. 39 429-447.

Richards A, Argles T, Harris N, Parrish R, Ahmad T, Darbyshire F and Draganits E 2005 Himalayan architecture constrained by isotopic tracers from clastic sediments; Earth Planet. Sci. Lett. 236 $773-796$.

Saini N K, Mukherjee P K, Rathi M S and Khanna P P 2000 Evaluation of energy-dispersive x-ray fluorescence spectrometry in the rapid analysis of silicate rocks using pressed powder pellets; X-Ray Spectrometry 29(2) 166-172.

Shalkowasky A, Kodama Y and Nakano S 2008 The assessment of weathering stages in granites using an $\mathrm{EC} / \mathrm{pH}$ meter; Geomorphology 105 253-260.

Sharma A and Rajamani V 2000 Weathering of gneissic rocks in the upper reaches of Cauvery river, south India: Implications to neotectonics of the region; Chem. Geol. $166203-223$.

Smyth 1913 Relative solubility of the chemical constituents of rocks; J. Geol. 21 105-120.

Srivastava P and Mitra G 1994 Thrust geometries and deep structure of the outer and lesser Himalaya, Kumaun and Garhwal (India): Implications for evolution of the Himalayan fold-and-thrust belt; Tectonics 13 89-109.

Srivastava P, Tripathi J K, Islam R and Jaiswal M K 2008 Fashion and phases of late Pleistocene aggradation and 
incision in the Alaknanda River Valley, western Himalaya, India; Quat. Res. 70 68-80.

Stork A L, Smith D K and Gill J B 1987 Evaluation of geochemical reference standards by $\mathrm{X}$-ray fluorescence analysis; Geostand. Newsletter 11 107-113.

Sun S S and McDonough W F 1989 Chemical and isotopic systematics of oceanic basalts: Implications for mantle composition and processes; In: Magmatism in Ocean Basins (eds) Sunders A D and Norry M J, Geol. Soc. Spec. Publ. 42 313-345.
Turner B F, Stallard R and Brantley S L 2003 Investigation of in situ weathering of quartz diorite bedrock in the Rio Icacos basin, Luquillo experimental forest, Puerto Rico; Chem. Geol. 202 313-341.

Valdiya K S 1980 Geology of Kumaun Lesser Himalaya; Wadia Institute of Himalayan Geology, Dehradun, $228 \mathrm{p}$.

Vyshnavi S, Islam R, Srivastava P and Mishra D K 2013 Elemental behaviour in the soil profile of the humid north eastern Himalaya; Him. Geol. 34(1) 65-75. 